\title{
Grafik dan Muzik: Analisis Reka Bentuk Kulit Album
}

\author{
SALZIANA IBRAHIM \\ RAJA ISKANDAR RAJA HALID \\ Universiti Malaysia Kelantan
}

\begin{abstract}
ABSTRAK
Kulit album mempunyai pelbagai fungsi pada sesebuah karya seni muzik. Reka bentuk kulit album yang menarik mampu menarik pelanggan untuk membuat pilihan ketika membeli produk tersebut. Kajian ini bertujuan untuk mengkaji hubungan grafik dan muzik terhadap empat buah kulit album Zainal Abidin iaitu album Hijau, Gamal, Orak Arek dan Terangsang. Sememangnya tidak dapat dinafikan bahawa reka bentuk kulit album telah banyak mengalami perubahan dari pelbagai aspek mengikut perkembangan industri muzik. Pelbagai teknik reka bentuk digunakan untuk menyampaikan mesej berhubung kait dengan genre album tersebut. Kajian kes dalam kaedah kualitatif ini menggunakan teknik pemerhatian dan fotografi terhadap empat buah kulit album Zainal Abidin sebagai artis pop yang terkenal dengan keunikan lagunya di Malaysia. Data yang dikumpul telah dianalisis dan dinilai dari segi grafik berdasarkan tiga elemen iaitu warna, visual dan tipografi yang digunakan manakala, dari segi muzik pula dilihat dari elemen ritma, bunyi dan lirik lagu dalam album itu. Analisis kulit album ini juga dibuat berlandaskan pendekatan semiotik sosial komunikasi visual oleh Van Leeuwen dalam menjelaskan makna di sebalik reka bentuk kulit album yang disampaikan. Hasil kajian menunjukkan hubungkait antara grafik dan muzik pada keempat-empat kulit album yang dijadikan kajian kes ini. Oleh hal demikian, hubungan antara reka bentuk grafik dan album muzik tidak dapat dipisahkan untuk menghasilkan kulit album yang berkualiti di samping menyampaikan maklumat komunikasi dengan berkesan.
\end{abstract}

Kata kunci: Grafik, muzik, reka bentuk, kulit album, tipografi.

\section{Graphic and Music: An Analysis of Album Cover Design}

\begin{abstract}
The album cover has a variety of functions in a musical artwork. Attractive album cover design is able to attract customers to make a choice when buying a product. This study aims to analyze the relationship of graphics and music in Zainal Abidin's album cover designs of four of his albums: Hijau, Gamal, Orak Arek and Terangsang. It is undeniable that album cover designs have evolved from various aspects in accordance with the development of the music industry. Various design techniques are used to convey messages related to the genre of the album. This case study utilises qualitative methods that use observation and photography techniques on the four album covers of Zainal Abidin, who is a famous pop artist, known for his unique songs in Malaysia. The collected data were analyzed and evaluated graphically based on three elements namely colours, visuals and typography while, in the terms of music, the study looks at the rhythm, sound and lyrics of the songs in the album. Analysis of the album cover is also made based social semiotic approach to visual communication by Van Leeuwen in explaining the meaning behind the album cover designs submitted. In conclusion, the relationship between graphics and music can be seen in all four album covers this case study. As such, the relationship between graphic design and music cannot be separated to produce album covers of high quality while communicating effectively.
\end{abstract}

Keywords: Graphics, music, design, album cover, typography. 


\section{PENGENALAN}

Kulit album atau cover mempunyai berbagai fungsi pada sebuah karya seni muzik. Selain untuk melindungi kandungan, kulit album juga bermaksud lambang kepada imej iaitu kaedah yang digunakan oleh pengiklan untuk menarik perhatian khalayak dengan memperkenalkan sesuatu produk. Hal ini bermaksud para penerbit perlu meneliti keadaan semasa terutama dalam perkembangan seni muzik mengikut tema kerana ianya merupakan sumber ilham pereka sesebuah kulit album. Kulit album adalah salah satu daya tarikan pelanggan untuk membuat pilihan ketika membeli produk tersebut. Kulit album yang mempunyai reka bentuk menarik mampu menjadi satu penyampaian baik kepada pelanggan sebagai alat hubungan penerbit dan artis dengan pelanggan.

Menurut Guiltinan dan Paul (1990), berdasarkan analisis situasi dan strategi pemasaran, setiap penerbit bertanggungjawab untuk menjelaskan maksud setiap reka bentuk grafik tersebut. Sebagai alat penyampaian yang berkesan, kulit album direka dengan baik supaya kandungannya mampu difahami oleh masyarakat terutamanya dari segi reka bentuk yang disampaikan oleh pereka dan boleh menyampaikan imej produk tersebut. Kulit album merupakan sebuah pembungkusan seni yang menarik kepada sesebuah produk seperti album sama ada dalam bentuk piring hitam, kaset atau CD. Kulit album adalah karya seni, dengan reka bentuk grafik yang dipilih, kulit album ini dapat menyampaikan mesej yang boleh menyampaikan maklumat secara tepat dan teliti.

Reka bentuk grafik merupakan seni berkaitan komunikasi dan proses penciptaan bentuk visual, proses komunikasi visual yang menggabungkan teks dan ilustrasi yang membentuk logo, grafik, risalah poster, kulit album, kulit buku, buletin dan lain-lain. Menurut Noresah (2007), grafik membawa maksud maklumat atau paparan yang terdiri daripada lukisan, gambar rajah, simbol, warna, tipografi dan lain-lain untuk menyatakan atau menyampaikan idea.

\section{SOROTAN KARYA}

Perbincangan berkaitan kulit album telah lama dilakukan, namun di antara kajian dan dokumentasi berkaitan kulit album Barat yang paling menyeluruh telah dilakukan oleh Thorgerson dan Dean (1977). Thorgerson merupakan seorang pereka kulit album yang terkenal dan telah menghasilkan rekaan kulit-kulit album termasyhur di dunia, termasuk dari kumpulan Pink Floyd, Bad Company, Led Zeppelin dan The Police. Bersama Roger Dean, Thorgerson telah menerbitkan beberapa siri buku dari tahun 1977 sehingga 2008 yang bertajuk "Album Cover Album". Di dalam terbitan pertama, terdapat penerangan berkaitan sejarah perkembangan kulit album di Amerika yang ditulis oleh Dominy Hamilton (dinyatakan dalam Thorgerson \& Dean, 1977). Beliau membincangkan tentang kemunculan terma 'album' itu sendiri dan bagaimana aspek visual mula menguasai kulit album. Menurut Hamilton (dlm. Thorgerson \& Dean, 1977):

"Starting before 1920, books of records bound together had been available this is the origin of the term 'album' which strictly speaking, is a misnomer in its present day usage" (hlm. 9).

Menurut Libeks dan Turnbull (2010), melalui artikel mereka "You Can Judge an Artist by an Album Cover: Using Images for Music Annotation", kulit album yang menggunakan imej dapat memberi penjelasan yang mendalam terhadap sesebuah album muzik tersebut. Dengan maklumat visual yang disampaikan boleh membantu dalam pencarian sesebuah 
album muzik melalui media massa dengan mudah. Dapatan kajian yang boleh disimpulkan dari kajian ini ialah hubungan antara reka bentuk dengan muzik tidak dapat dipisahkan dari pelbagai aspek. Kulit album telah banyak mengalami perubahan dari pelbagai aspek mengikut perkembangan industri muzik dan memberi kesan kepada masyarakat melalui imej-imej yang terdapat pada rekaan kulit album itu sendiri. Pelbagai teknik reka bentuk telah digunakan untuk menghiasi kulit album genre muzik ini dan setiap rekaannya mempunyai mesej tertentu untuk disampaikan kepada masyarakat. la juga berhubung kait dengan seseorang artis kumpulan tersebut seperti konsep, muzik dan imej yang dibawanya (Libeks \& Turnbull, 2010).

Selain dari itu, kajian tertumpu pada perkembangan muzik tanah air. Hal ini dapat dilihat melalui kajian Norshafawati, Asiah dan Fuziah (2010) yang membincangkan perspektif isu dasar yang berkaitan industri muzik dengan meneroka isu-isu tersebut melalui data yang dikumpul melalui kaedah analisis kandungan akhbar. Dapatan kajian ini jelas menyatakan penelitian kepada pemaparan dasar yang berkaitan dengan industri muzik adalah antara usaha dalam melihat perkembangan pembangunan industri berkenaan dalam konteks pembangunan sosial masyarakat.

Menurut Hanafi, Normah dan Wan Amizah (2018), reka bentuk kulit buku terhasil daripada proses mereka letak dan menyusun atur tipografi serta visual. Visual merupakan elemen penting dalam seni reka grafik di mana ia banyak menyumbang di dalam proses penerbitan sesuatu bahan cetakan seperti buku, majalah, poster dan lain-lain lagi. Penampilan visual melalui teknik illustrasi dan fotografi merupakan dua teknik yang seringkali digunakan di dalam proses reka letak dan susun atur dalam sesuatu bahan cetakan termasuklah kulit album sesebuah muzik. Dalam kajian ini, pengkaji juga melihat ilustrasi dan fotografi yang terdapat pada reka bentuk kulit album Zainal Abidin.

Mustaffa@ @apa (Berita Hiburan, 2016) menjelaskan bahawa kulit album dapat memperlihatkan evolusi fesyen daripada 70-an, 80-an, 90-an sehingga kini. Kulit album yang dihasilkan bukan sekadar kulit album tetapi ia mengenai pengarkiban warisan budaya pop dan industri muzik Malaysia. Berdasarkan kajian Tapa ini juga, peranan seni reka grafik sememangnya penting untuk menghasilkan suatu rekaan yang kreatif dan idea-idea yang bernas dalam setiap reka bentuk seperti reka letak yang bersesuaian, pemilihan tipografi, warna, imej dan lain-lain untuk sesebuah penerbitan dengan tujuan pemasaran pada setiap rekaan grafik, hasil dari gabungan elemen-elemen tertentu mampu menjadi daya tarikan utama kepada mutu penjualan album muzik.

Seterusya, kajian ini sendiri telah memperlihatkan kolerasi antara visual dan muzik, yang diperluaskan lagi dari sudut analisis grafik dan lirik serta irama. Berdasarkan pemerhatian dan juga dapatan kajian lepas mendapati kolerasi sebegini tidak mendapat perhatian sewajarnya daripada para sarjana. Oleh sebab itu, kajian hubungkait antara grafik dan muzik dikaji dan dianalisis secara mendalam bagi menghurai maksud di sebalik reka bentuk sesebuah kulit album.

\section{METODOLOGI}

Kajian ini meneliti hubungkait antara grafik dan muzik pada kulit album Zainal Abidin iaitu Hijau, Gamal, Orak Arek dan Terangsang. Kaedah kualitatif telah digunakan iaitu pengumpulan data berbentuk oral dan visual melalui sumber dokumentasi, pemerhatian serta fotografi. Kajian ini juga berlandaskan pendekatan semiotik dalam menganalisis gambar pada kulit album yang dikaji. Menurut Van Leeuwen (2004, hlm.2-3), semiotik sosial 
komunikasi visual melibatkan penerangan mengenai sumber semiotik iaitu apa yang boleh dikatakan dan dilakukan dengan imej serta bagaimana imej tersebut ditafsirkan. Beliau juga menerangkan semiotik sosial bukan sahaja untuk mengumpul dan menyiasat sumbersumber semiotik tetapi bagaimana ianya digunakan dalam konteks tertentu. Oleh hal demikian, tiga elemen grafik iaitu warna, visual dan tipografi manakala elemen muzik iaitu ritma, bunyi dan lirik dianalisis dalam kajian ini bagi melihat kolerasi antara grafik dan muzik dalam menghasilkan reka bentuk kulit album.

\section{HASIL KAJIAN DAN PERBINCANGAN}

Dalam kajian kes ini, empat kulit album Zainal Abidin tahun 90-an iaitu Hijau, Gamal, Orak Arek dan Terangsang telah dipilih untuk melihat kaitan antara reka bentuk grafik dan genre muzik itu sendiri. Peranan reka bentuk komunikasi visual pada kulit album masing-masing mempunyai maksud penyampaian yang berbeza untuk berinteraksi antara satu sama lain dan mewujudkan satu kesatuan bentuk dan kesatuan makna yang penting. Memandangkan permasalahan yang dikemukakan adalah kaitan grafik dan muzik dalam reka bentuk kulit album, pendekatan semiotik makna denotatif dan konotatif, maka kajian mengenai elemen seni grafik dan elemen muzik perlu dikaji bagi melihat kaitannya dengan jelas.

Jadual 1 merupakan senarai elemen reka bentuk grafik dan elemen muzik secara keseluruhan namun elemen yang ketiga dari atas itu sahaja dipilih untuk dilihat dalam kajian ini. Pemilihan dibuat berdasarkan kepentingan dan keserasian hubungkait atau kolerasi antara grafik dan muzik terhadap penghasilan reka bentuk kulit album.

Jadual 1: Elemen Grafik / Komunikasi Visual, Suhanto (1999)

Elemen Muzik, Rashidah dan Naimah (2009)

\begin{tabular}{|ll|}
\hline Elemen Grafik & Elemen Muzik \\
Tipografi & Lirik \\
Warna & Ritma \\
Ilustrasi & Bunyi \\
Ruang (Space) & Harmoni \\
Garisan (Line) & Tekstur \\
Bentuk Tiga Dimensi (Form) & Bentuk \\
Rupa Dua Dimensi (Shape) & Melodi \\
Permukaan/Jalinan (Sufface) & Ekspresi \\
\hline
\end{tabular}

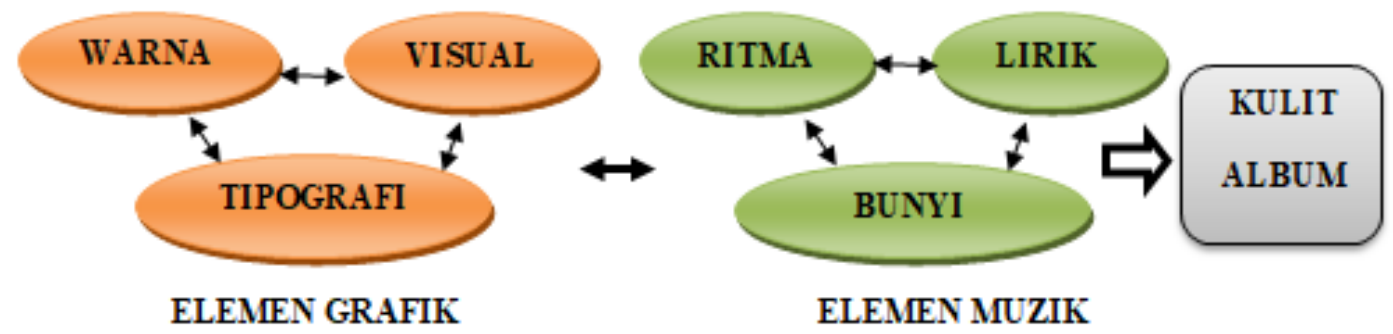

Rajah 1: Kerangka Kajian 
Rajah 1 merupakan kerangka kajian tentang hubungan reka bentuk grafik dan muzik pada kulit album yang dikaji. Elemen grafik yang dilihat dalam kajian ini ialah warna, visual dan tipografi manakala elemen muzik pula ialah ritma, lirik dan bunyi (sound). Berikut dapatan kajian yang diperoleh berdasarkan kerangka kajian di atas.

\section{1) Elemen grafik}

a) Warna

Menurut Kusrianto (2009, hlm.47), warna adalah imej pelengkap dan mewakili suasana psikologi pelukis dalam berkomunikasi. Warna juga merupakan elemen yang sangat tajam untuk menyentuh sensitiviti penglihatan untuk merangsang kemunculan perasaan, kesedihan, kegembiraan, suasana hati, atau semangat, dan sebagainya. Jadual 2 merupakan senarai warna dan maksud psikologi menurut Molly E. Holzschlag (dalam Kusrianto, 2009) yang digunakan dalam kajian ini.

Jadual 2: Warna dan maksud psikologi

\begin{tabular}{ll}
\hline Warna & \multicolumn{1}{c}{ Maksud Psikologi } \\
\hline Merah & Kekuatan, tenaga, kehangatan, nafsu, cinta, agresif, bahaya. \\
Biru & Amanah, konservatif, keselamatan, teknologi, kebersihan, perintah. \\
Kuning & Asli, kesihatan, penampilan yang baik, cemburu, pembaharuan. \\
& Optimisme, harapan, falsafah, ketidakjujuran / penipuan, pengecut, \\
Ungu & Rengkhianatan. \\
Oren & Tenani, misteri, keagungan, perubahan bentuk, sengit, sombong. \\
Coklat & Asli, Bumi, boleh dipercayai, selesa, bertahan. \\
Kelabu & Intelek, futuristik, bergaya, kesepian, merosakkan. \\
Putih & Kesucian / suci, bersih, tepat, tidak bersalah (tanpa dosa), steril, kematian. \\
Hitam & Kekuatan, seksualiti, kemewahan, kematian, misteri, ketakutan, kesedihan, \\
& keanggunan. \\
\hline
\end{tabular}

\section{b) Visual}

Menurut Suharto (1999), unsur-unsur visual dalam reka bentuk grafik disusun dalam pelbagai penampilan yang bervariasi atau berbeza-beza. Oleh itu, pengkaji perlu melihat unsur-unsur visual dari segi kedudukan, arah dan jarak. Kedudukan adalah masalah di mana suatu objek yang terbentuk oleh unsur-unsur visual ditempatkan. Dalam kajian ini, pengkaji perlu melihat kedudukan atau reka letak pada sesebuah kulit album yang dikaji bagi mengesan visual yang ditegaskan. Unsur visual yang kedua iaitu arah, pilihan mengenai arah mana objek dihadapkan dan bagaimana kesannya terhadap hubungan suatu objek dengan objek lain. Seterusnya ukuran adalah untuk menentukan kesan saiz visual yang dipamerkan sesuai dengan peranannya. Manakala bagi jarak, bentuk dan jumlah berpengaruh terhadap kepadatan, berat serta keluasan ruang atau bidang di mana berbagai objek dihadirkan.

\section{c) Tipografi}

Menurut Sihombing (2007), tipografi adalah bidang ilmu mengenai huruf yang mempunyai dua fungsi iaitu fungsi estetik dan fungsi komunikasi. Dalam kajian ini, pengkaji melihat jenis-jenis huruf dari dua sudut iaitu huruf diklasifikasikan ke dalam beberapa jenis (Craig, dinyatakan dalam Sawa, 2014) dan klasifikasi huruf berdasarkan sejarah dan bentuk huruf (Lawson, dinyatakan dalam Sawa, 2014). 


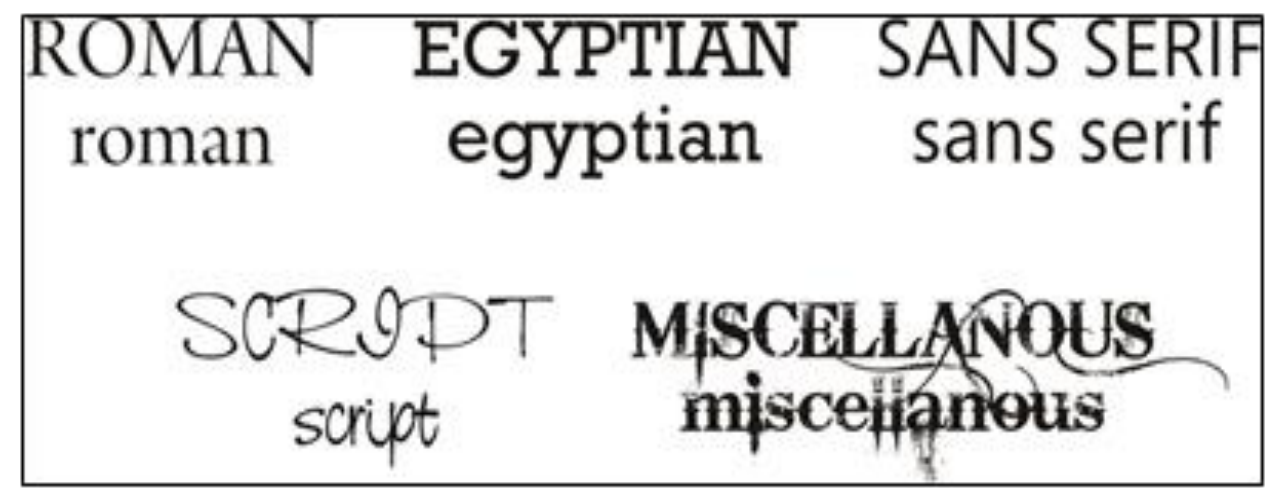

Rajah 2: Jenis-jenis huruf menurut James Craig (dlm. Sawa, 2014)

(Sumber: https://www.dumetschool.com/blog/Teori-Tipografi-Jenis-Huruf-Part-1)

Rajah 2 menunjukkan jenis-jenis huruf berdasarkan James Craig (dlm. Sawa, 2014). Terdapat lima jenis huruf yang dinyatakan ciri dan kesannya terhadap bentuk sesebuah tipografi pada reka bentuk kulit album. Huruf-hurufnya ialah:

i. Roman. Kesan yang ditimbulkan adalah mengekspresikan organisasi dan intelektualitas, klasik, anggun, lemah gemulai.

ii. Egyptian. Kesan yang ditimbulkan adalah kuat dan stabil.

iii. Sans Serif. Kesan yang ditimbulkan oleh huruf jenis ini adalah moden dan kontemporari.

iv. Script. Kesan yang ditimbulkannya adalah sifat peribadi dan akrab.

v. Miscellaneous. Kesan yang dimiliki adalah dekoratif dan ornamental.

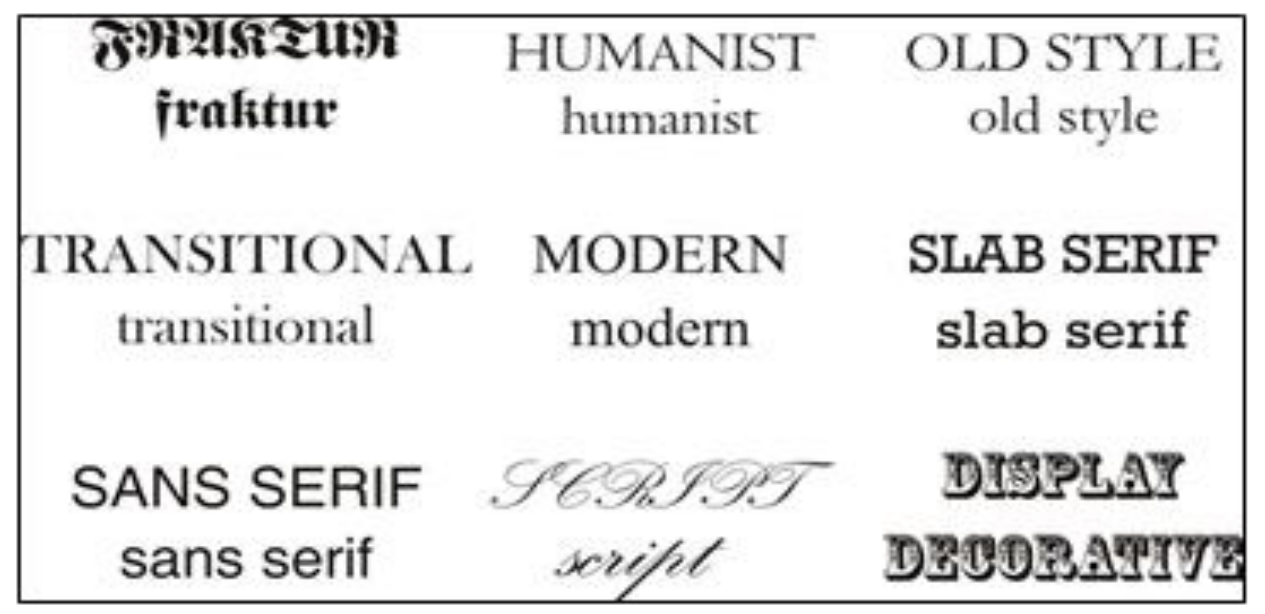

Rajah 3: Jenis-jenis huruf menurut Alexander Lawson (dlm. Sawa, 2014)

(Sumber: https://www.dumetschool.com/blog/Teori-Tipografi-Jenis-Huruf-Part-1)

Rajah 3 pula menunjukkan jenis-jenis huruf menurut Lawson (dlm. Sawa, 2014) iaitu klasifikasi huruf berdasarkan sejarah dan bentuk huruf. Terdapat sembilan jenis huruf yang dinyatakan ciri dan kesannya iaitu:

i. Black Letter/Old English/Fraktur. Kesan yang ditimbulkan adalah klasik, gelap, berat dan hitam.

ii. Humanist/Venetian. Kesan yang ditimbulkan adalah terang, ringan dan manusiawi.

iii. Old Style/Old Face/Garalde. Karakter-karakter pada kelompok typeface ini lebih lancip, lebih kontras dan berkesan lebih ringan, menjauhi bentuk-bentuk ukiran/tulisan tangan.

iv. Transitional/Reales. Kelompok ini disebut Transitional karena berada diantara Old Style dan Modern. 
v. Modern/Didone. Jenis ini dinamakan Modern karena kemunculan kelompok typeface ini pada akhir abad 17, menuju era yang disebut Modern Age.

vi. Slab Serif/Egyptian. Ciri dari jenis huruf ini iaitu memiliki kaki/sirip/serif yang patah.

vii. Sans Serif. Popular pada awal abad 20, di mana pereka mencari bentuk-bentuk ekspresi baru yang mewakili sikap penolakan terhadap nilai-nilai lama, iaitu pengkotakkan masyarakat dalam kelas-kelas tertentu. Ciri dari jenis huruf ini iaitu tidak memiliki kaki/sirip/serif.

viii. Script \& Cursive. Ciri dari jenis huruf ini iaitu tidak memiliki kaki/sirip/serif tetapi seringkali digantikan oleh tambahan pada terminal atau bahagian hujung huruf yang bersifat dekoratif.

ix). Display/Decorative. Ciri dari jenis huruf ini iaitu memiliki kaki/sirip/serif yang sangat bervariasi dan bersifat dekoratif.

\section{2) Elemen Muzik}

Tiga elemen muzik iaitu ritma, lirik dan bunyi dilihat pada reka bentuk kulit album yang dikaji. Berikut adalah penerangan tiga elemen muzik tersebut:

\section{a) Ritma}

Menurut Miller dan Shahriari (2012), berdasarkan petikan di bawah menjelaskan irama pada dasarnya merupakan jangka masa bunyi yang polanya sukar diramal.

"Rhythm is essentially the relationship of sound durations. Some rhythms fall into regular patterns while others are less predictable" (2012, hlm.29).

Menurut Miller dan Shahriari lagi, irama terbahagi kepada tiga aspek iaitu bit (beat), tempo aksen (accent) dan meter seterusnya ketumpatan irama. Berdasarkan istilah Dewan Bahasa dan Pustaka, bit (beat) merupakan nadi asas dalam setiap karya muzik. Bit (beat) boleh berlaku secara cepat atau perlahan berdasarkan tempo dalam setiap karya muzik. Kamus Pelajar Edisi Kedua pula menjelaskan tempo sebagai ukuran waktu dalam muzik. Bit (beat) ialah denyutan biasa atau bunyi. Kadar atau kelajuan ini dipanggil tempo. Dengan cara yang sama, rentak muzik boleh menjadi agak cepat atau lambat berhubung dengan rentak asas.

Menurut Kamus Dewan Edisi Keempat, definisi aksen ialah tekanan suara (bunyi) pada kata atau suku kata dan maksud kedua ialah cara seseorang dari sesebuah daerah menggunakan loghat mereka dalam lagu tersebut. Aksen (accent) sering digunakan untuk menunjukkan struktur berirama yang mendasari persembahan muzik. Meter pula bermaksud tanda masa untuk menetapkan jenis ritma dan sukatan masa setiap bar sesuatu karya muzik. Dalam kes lain, seperti yang sering berlaku di Afrika, pemuzik tidak berfikir tentang meter tetapi dari segi bagaimana irama dikaitkan. Sebaliknya muzik bermeter adalah muzik dalam irama bebas. Muzik sedemikian tidak mempunyai nada biasa tetapi dengan menggunakan ucapan.

Ketumpatan irama digambarkan sebagai satu struktur atau siri berterusan antara rendah dan tinggi (atau nipis dan tebal). Contohnya boleh dengar dari gabungan pelbagai bunyi Afrika yang menjadikannya unik (FOLI original version by Thomas). 


\section{a) Lirik}

Menurut Waluyo (2002, hlm.1), lirik lagu dapat dipandang sebagai salah satu karya seni bersifat tertulis yang bentuknya mirip dengan puisi. Bahasa pada lirik lagu merupakan bahasa yang dipadatkan, dipersingkat, dan diberi irama dengan bunyi yang padu dan pemilihan katakata kias dan imaginasi. Manakala menurut Purwanto (2011, hlm.2), lirik sebagai bahasa ekspresi manusia yang melalui proses kreatif sehingga dipenuhi dengan makna dan perlu diterjemahkan. Di dalam sebuah lagu juga terdapat lirik yang memiliki makna dan implikasiimplikasi tertentu.

\section{b) Bunyi (Sound)}

Menurut Snyder (2001), bunyi merupakan elemen kolektif yang disimpan di dalam minda seseorang sebagai ingatan yang wujud melalui pengalaman. Daya pendengaran setiap manusia secara umum mencetuskan pemikiran yang berbeza apabila mendengar irama-irama tertentu. Tanggapan terhadap sesuatu bunyi berubah-ubah dengan bantuan visual dan sebagai contoh, muzik rock dianggap sebagai jenis muzik yang agresif serta ganas. Seperti dalam kajian ini, bunyi dalam lagu dapat menimbulkan konsep yang digunakan dan banyak mempengaruhi elemen grafik dalam penghasilan reka bentuk kulit album.

\section{ANALISIS KAJIAN}

Seperti yang dibincangkan sebelumnya, kajian ini bertujuan untuk mengkaji hubungan grafik dan muzik terhadap reka bentuk kulit album Zainal Abidin iaitu kulit album Hijau, Gamal, Orak Arek dan Terangsang. Menurut Beng (2009, hlm.70), Zainal Abidin dikenali sebagai "semangat ekstrem muzik etnik" dan "perintis dalam penggabungan gabungan etnik dan World Music". Beliau telah membawa muzik Malaysia ke negara-negara Asia lain seperti Jepun, Indonesia, Hong Kong, Singapura, Taiwan, Korea serta Australia dan Perancis melalui konsert secara langsung dan promosi albumnya termasuk Zainal Abidin (Hijau), Gamal, Orak Arek, dan Terangsang (Bintang, 8 Ogos 1996, NST, 5 Jun 1994).

Zainal Abidin bin Mohamad atau lebih dikenali sebagai Zainal Abidin atau Zainal Headwind (lahir 4 November 1959) merupakan seorang penyanyi lelaki Malaysia. Beliau ialah bekas penyanyi kumpulan Headwind sebelum mengorak langkah sebagai penyanyi solo pada tahun 1989 menerusi album pertamanya yang menggunakan namanya sebagai judul album yang diterbitkan oleh Roslan Aziz Production (RAP) pada 1991.

Zainal telah memenangi banyak anugerah di dalam negara dan di Jepun dan telah muncul di MTV Asia yang dipancarkan di Hong Kong, Jepun, Korea, Taiwan dan negara-negara lain. Beliau adalah orang Malaysia yang pertama di festival WOMAD (World of Music, Arts and Dance) yang mewakili Malaysia di Yokohama pada tahun 1992 (Bintang, 7 Sept 1992, 22 Feb 1992).

Sepanjang kerjaya muzik beliau, Zainal Abidin terkenal dengan lagu-lagu yang bergenre muzik dunia dan kerohanian yang banyak berkisarkan tentang kasih sayang, kemanusiaan dan alam sekitar melalui liriknya dan berjaya mencuri perhatian para pendengar dan diterima oleh masyarakat tempatan dan antarabangsa. Bersama kumpulan Headwind, beliau telah menghasilkan sebanyak 8 album sebelum meninggalkan kumpulan itu pada 1989 untuk memulakan kerjaya muzik beliau secara solo pada 1990. Dalam kerjayanya sebagai penyanyi solo, Zainal Abidin telah melahirkan 4 album solo yang paling diiktiraf dan berjaya merevolusikan perubahan besar kepada industri muzik Malaysia. 
Zainal Abidin (digayakan sebagai ZAINAL abidin) ialah album studio pertama beliau yang dilancarkan pada 1991. Melalui album pertamanya ini, Zainal mengetengahkan konsep World Music dan popular dengan lagu yang hits Hijau, Ikhlas Tapi Jauh dan Manis. World Music merupakan genre muzik yang membawakan aliran muzik tradisional yang kental dalam muziknya. Umumnya, genre World Music ialah seperti muzik tradisional atau muzik rakyat dari suatu budaya yang diciptakan dan dimainkan oleh pemuzik pribumi dan berkait erat dengan muzik dari daerah asal mereka. Boleh dikatakan bahawa World Music merupakan pengadaptasian muzik tradisional dengan muzik moden. Album ini diterbitkan oleh Roslan Aziz menerusi Roslan Aziz Productions (RAP) dan diedarkan oleh Warner Music Malaysia. Zainal merakamkan album solo pertamanya ini selepas beliau meninggalkan kumpulan Headwind.

Istilah 'World Music' dan 'World Beat' telah digunakan untuk menonjolkan muzik Zainal oleh pengkritik muzik dan dalam beberapa cara mereka "menggambarkan asas perkusi berat yang berfungsi sebagai batu loncatan untuk beberapa pengembaraan berirama yang membangkitkan kegelapan dengan Latin Amerika, Afrika dan Sentuhan orang India "(NST, 5 Januari 1994). Zainal juga menggabungkan irama tarian sosial Melayu seperti joget, keroncong, asli dan zapin serta etnik dari Sarawak. Zainal sendiri label kandungannya 'World Music' kerana mereka menggabungkan bunyi etnik dan moden. Alat muzik tradisional seperti Yang qin, sitar, gendang dan gambus saham terkenal dengan saksofon, keyboard, drum dan gitar (NST, 6 September 1996, 5 Jun 1994).

Zainal Abidin telah dirakamkan oleh Zainal Abidin, dengan Mukhlis Nor mengendalikan gubahan dan Roslan Aziz sebagai penerbit album. Pada masa itu, Zainal amat terpikat dengan pemuzik seperti Peter Gabriel, The Police dan Paul Simon dari negara Afrika. Album Simon, Graceland adalah terutamanya inspirasi utama untuk Zainal Abidin. Zainal berkata, objektif itu bukan untuk membuat album Melayu, tetapi album Malaysia. Beliau juga mahu mencipta muzik yang boleh membuat perbezaan.

Berikut merupakan analisis kajian terhadap empat kulit album Zainal Abidin iaitu Hijau, Gamal, Orak-Arek dan Terangsang.

1)

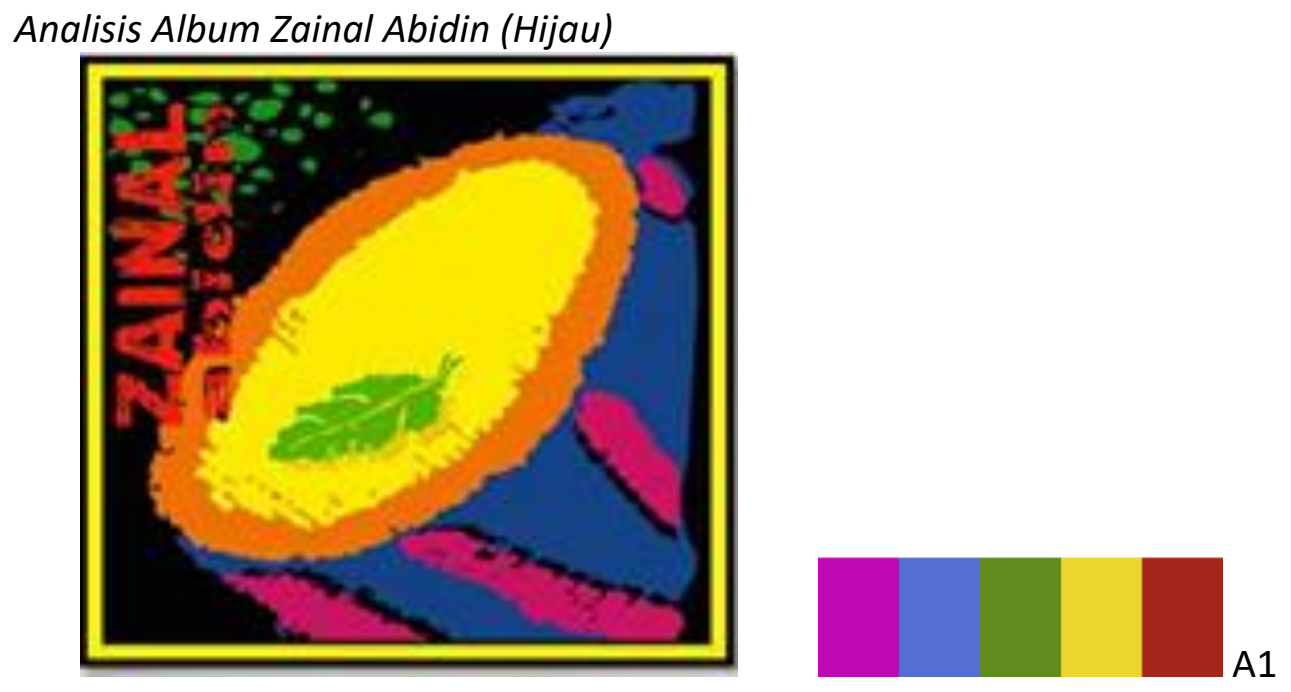

Rajah 4: Album Hijau

Zainal Abidin - Zainal Abidin

Label: WEA - 9031-74404-2, Roslan Aziz Productions - 9031-74404-2

Format: $C D$, Album 
Negara: Malaysia

Tahun keluaran: 1991

Genre: Pop

Senarai lagu:
1. Senang-senang
2. Telaga
3. Inayah
4. Baba
5. Damai IV
6. Insaf
7. Ikhlas tapi Jauh
8. Debu Liar
9. Manis
10. Hijau

Rajah 4 merupakan album solo Zainal Abidin yang pertama diterbitkan pada 30 Mei 1991 dengan meletakkan namanya sendiri pada kulit album iaitu "Zainal Abidin". Tiga elemen grafik dilihat dalam kajian ini iaitu tipografi, warna dan visual. Tipografi yang terdapat pada kulit album ini ditulis dengan menggunakan huruf Sans Serif pada perkataan "Zainal" dan Display Decorative pada "Abidin". Menurut Hasegawa dan Kobayashi (1985), teknologi komputer mempunyai kebebasan kepada pereka grafik untuk mencipta mesej dengan huruf, bukan hanya untuk membaca, tetapi juga mengekspresikan suasana atau rasa. Di sini dapat dilihat pada kulit album Hijau iaitu tipografinya seumpama corak "safari" sesuai dengan visual dan maksud lirik lagu yang disampaikan. Rajah 5 merupakan kumpulan huruf Afrika dari Anton Scholtz yang jelas menampakkan coraknya lebih kepada corak Safari, ini dijadikan perbandingan antara tipografi kulit album Hijau yang sememangnya mempunyai pengaruh kuat lagu-lagu yang bercirikan Afrika dalam lagu tersebut.

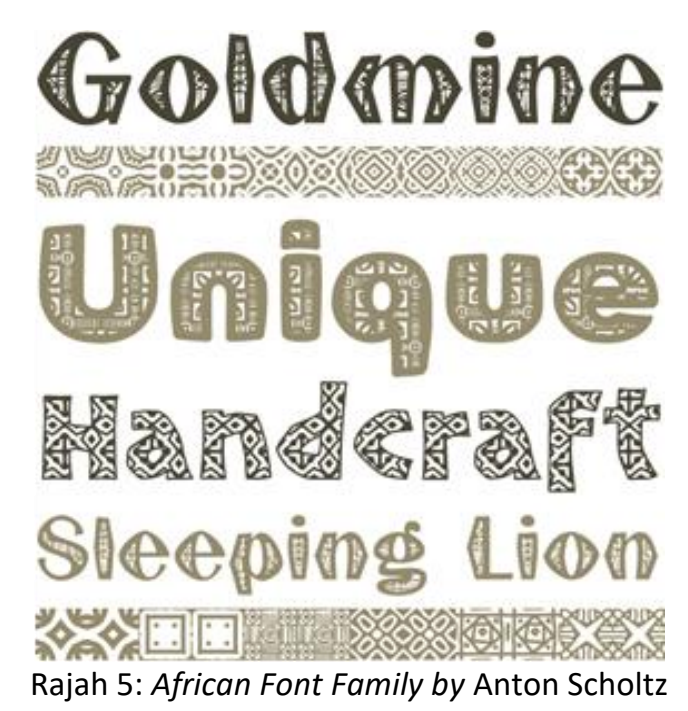

(Sumber: https://www.pinterest.com/pin/258957047299394531/)

Warna pula memainkan peranan dalam penghasilan reka bentuk kulit album hijau ini. Berdasarkan skala warna yang diambil pada kulit album ini dengan menggunakan Adobe Capture, terdapat lima warna iaitu ungu, biru, kuning, hijau dan merah. Merujuk warna dan maksud psikologi jadual 2 (Kustrianto, 2007): 
- Warna ungu melambangkan keagungan dan perubahan bentuk.

- Warna biru melambangkan teknologi dan kebersihan.

- Warna kuning melambangkan pengkhianatan.

- Warna hijau melambangkan asli dan pembaharuan.

- Warna merah melambangkan kekuatan, tenaga, agresif dan bahaya.

Pengkaji mendapati maksud psikologi di sebalik warna di Jadual 2 berkaitan dengan lirik lagu dalam album ini. Dari sudut semiotik seperti yang disebut oleh Van Leeuwen, makna representasi menyampaikan makna di sebalik tanda-tanda dan dengan itu, pengkaji telah melihat makna warna yang terdapat pada kulit album Hijau. Berdasarkan lirik, warnawarna tersebut dikaitkan dengan perubahan bentuk muka bumi akibat aktiviti hutan. Kejayaan manusia dalam perkembangan teknologi menyebabkan mereka hilang rasa tanggungjawab terhadap alam sekitar.

Seterusnya ilustrasi visual dilihat pada reka bentuk kulit album Hijau. Menurut beberapa elemen semiotik Van Leeuwen (2004) dalam menganalisis gambar, pengkaji telah melihat salah satu elemen iaitu point of view atau sudut pandangan terhadap kulit album ini. Sudut pandangan yang dilihat melibatkan gambar dalam bentuk dua dimensi namun menampakkan visual dari pelbagai kedudukan reka letak. Sudut pandangan utama pada kulit album Hijau ialah pada visual yang menyerupai permukaan gendang beserta sehelai daun di atasnya. Menurut Van Leeuwen juga, makna representasi dapat menjelaskan tanda-tanda yang ada pada sesebuah visual. Seperti tanda-tanda yang terdapat pada ilustrasi visual kulit album ini, imej gendang jelas kelihatan walaupun kedudukannya dalam keadaan senget. Daun yang berada di atas permukaan gendang tersebut pula melambangkan hutan juga alam sekitar dan warnanya pula seperti judul album iaitu Hijau. Pengkaji telah memahami lirik lagu dan mendapati ilustrasi visual tersebut dipilih sempena elemen muziknya yang pelbagai dari pengaruh Afrika serta gabungan muzik dunia (world music). Di sini boleh disimpulkan bahawa ilustrasi visual yang dipaparkan pada kulit album mempunyai kaitan yang rapat dengan muzik sesebuah album. Rajah 6 pula merupakan ilustrasi visual kulit album African Beat, oleh hal demikian secara jelas menunjukkan benua Afrika dengan gendang tidak dapat dipisahkan. Sehubungan dengan itu juga, kebanyakan kulit album muzik Afrika lebih kepada ilustrasi visual berbanding visual sebenar.

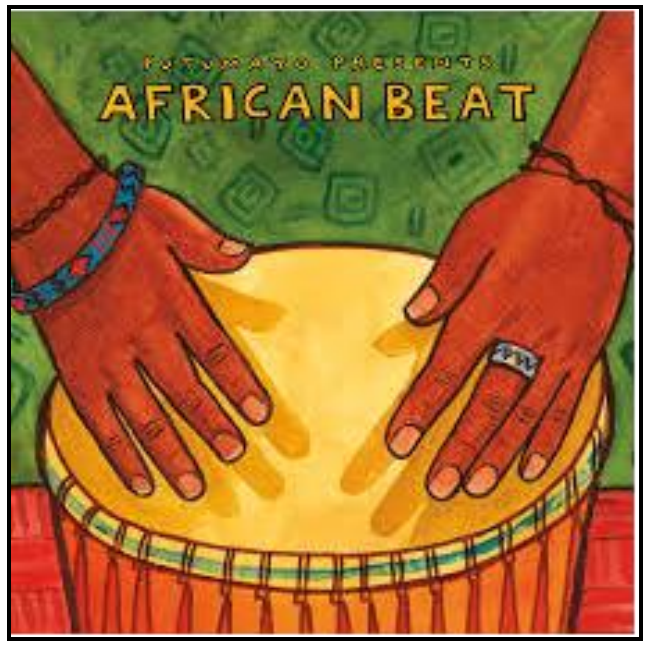

Rajah 6: African Beat (Re-Release)

(Sumber: https://www.putumayo.com/shop/african-beat/) 
Seterusnya kajian ini melihat reka bentuk kulit album berdasarkan elemen muzik. Album Hijau telah menggunakan pelbagai instrumen muzik Malaysia termasuk gamelan Melayu, Santoor, Sitar India, tabla serta peralatan muzik Cina Yangqin. Bunyi-bunyian dari peralatan muzik ini juga menimbulkan unsur World Music dalam lagu Zainal Abidin. Lagu Inayah juga jelas menggunakan bunyi-bunyian muzik India pada awal lagu dimainkan.

Lagu Hijau yang dicipta dan ditulis oleh Mukhlis Nor ini terkenal kerana mengangkat tema bumi serta alam sekitar yang semakin dicemari oleh manusia. Pencemaran yang berlaku disebabkan manusia terlalu mengejar arus pemodenan dan keuntungan wang ringgit. Bunyi dan rentak lagu dalam album ini menyerupai bunyi-bunyian Afrika selari dengan liriknya yang lebih kepada kemiskinan, penindasan kaum dan ketidakadilan yang selalu dikaitkan dengan benua tersebut.

Klip video lagu ini dengan gambar pokok, serangga, haiwan dan orang yang tinggal di hutan Malaysia telah dimainkan di televisyen nasional semasa Minggu Alam Sekitar Nasional pada 21-27 Oktober 1998. Menurut pernyataan Zainal Abidin dalam Star (1991), beliau menggunakan imej-imej tersebut dalam klip video kerana ingin menimbulkan beberapa masalah alam sekitar yang dihadapi. Rajah 7 merupakan antara keratan video klip lagu Hijau yang menunjukkan masalah alam sekitar berserta lirik lagu tersebut.
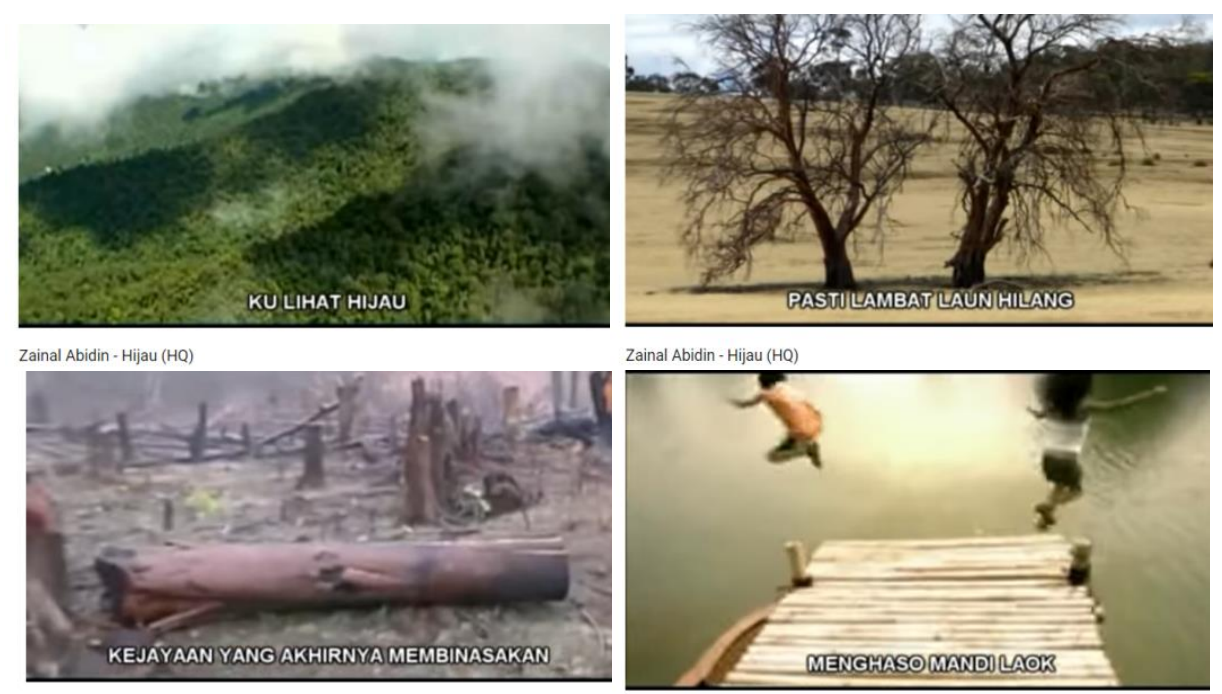

Zainal Abidin - Hijau (HQ)

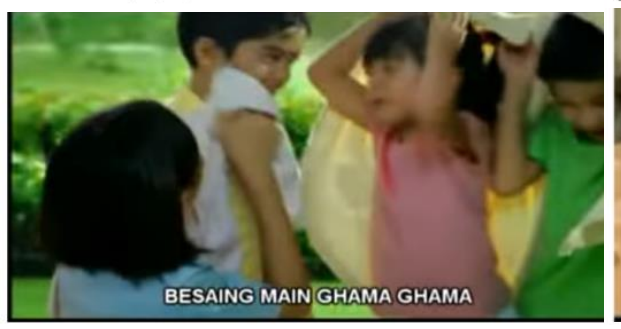

Zainal Abidin - Hijau (HQ)
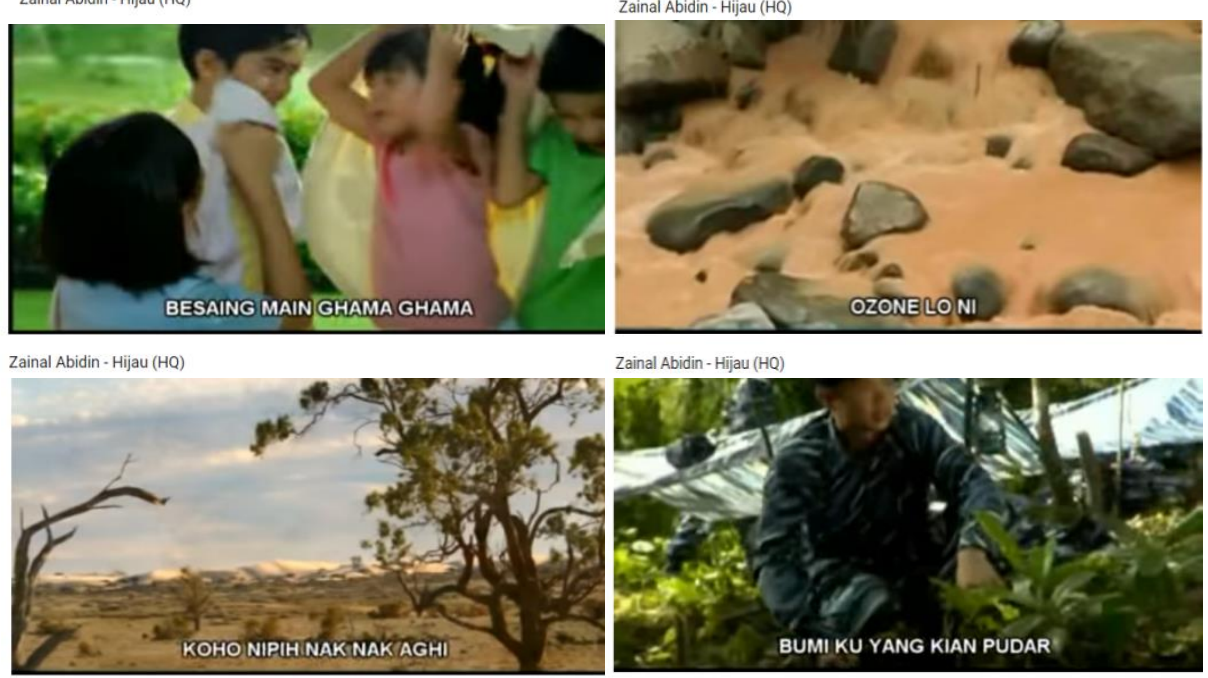

Zainal Abidin - Hijau (HQ)

Zainal Abidin - Hijau (HQ)

Zainal Abidin - Hijau (HO)

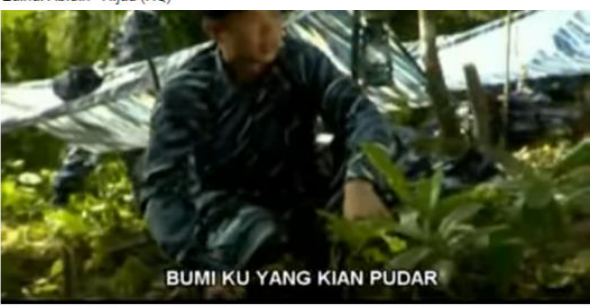

Rajah 7: Keratan Video Klip Lagu Hijau

(Sumber: https://www.youtube.com/watch?v=68PJW15iJSw) 
Lirik lagu yang dikarang oleh Mukhlis Nor ini merupakan campuran bahasa Melayu dan loghat Kelantan. Pada masa itu, Zainal inginkan sebuah lagu Malaysia dan korus lagu ini menampilkan nyanyian Zainal dalam loghat Kelantan yang agak unik untuk rakaman arus perdana. Pengkaji mendapati penggunaan loghat Kelantan dalam lagu ini kerana Zainal ingin mengekalkan keaslian bahasa tradisional selari dengan lirik lagu yang mengekalkan keaslian alam sekitar. Loghat Kelantan yang digunakan juga berjaya menunjukkan bunyian Afrika di mana ia memberi kesan kepada pendengar luar yang tidak faham bahasa Kelantan dan lenggok lagu yang dinyanyikan seolah-olah bunyian Afrika. Berikut merupakan petikan lirik loghat Kelantan yang terdapat dalam lagu Hijau.

\author{
Oh anok-anok \\ Tok leh menghaso mandi laok \\ Besaing main ghama-ghama \\ Ale lo ni tuo umonyo berjuto \\ Kito usoho \\ Jauhke daghi malapetako \\ Ozon lo ni koho nipih nak nak aghi \\ Keno make asak hok biso we pakso manusio \\ Seghemo bendo-bendo di dunio tok leh tehe \\ Sapa bilo-bilo
}

Hijau (Loghat Kelantan) (Album: Zainal Abidin, 1991)

Zainal Abidin menyanyi korus di dalam loghat Kelantan untuk mengekspresikan nostalgia terhadap alam sekitar yang bersih di mana kanak-kanak dapat bermandi laut dan bernafas dengan udara yang bersih. Pengkaji menterjemahkan maksud loghat di atas kepada bahasa Melayu moden yang bermaksud anak-anak tidak lagi dapat merasa mandi laut dengan kawan-kawan. Usaha perlu dilakukan untuk menjaga alam yang sudah lama usianya supaya dijauhkan dari mala petaka. Ozon yang semakin hari semakin nipis menyebabkan manusia tiap-tiap hari menyedut asap merbahaya dan kehidupan alam yang ada di dunia sekarang tidak dapat bertahan lama. Oleh itu boleh disimpulkan bahawa lagu dalam album Hijau ini sememangnya mempunyai maksud penindasan dan pemusnahan alam sekitar. Bunyi tradisional seperti dialek, instrumen dan irama membangkitkan nostalgia untuk budaya Malaysia serta Asia. Lirik berikut juga memaklumkan pendengar mengenai kepentingan alam sekitar.

Bumi yang tiada udara

Bagai tiada nyawa

Pasti hilang suatu hari

Tanpa disedari...

Bumiku yang kian pudar

Siapa yang melihat?

Hijau (Album: Zainal Abidin, 1991) 
Lagu Manis dalam album Hijau juga antara lagu world music yang mengetengahkan muzik Afrika dan telah berjaya menunjukkan bunyi-bunyian Afrika dari suara Zainal Abidin sendiri. Bunyi tersebut jelas kedengaran pada permulaan lagu tersebut iaitu:

\section{'Umbebe' \\ 'Umbebe'}

Manis (Album: Zainal Abidin, 1991)

Berdasarkan analisis kulit album Hijau, pengkaji mendapati terdapat kolerasi antara grafik dan muzik dalam penghasilan kulit album ini. Penggunaan tiporafi, warna dan visual jelas dilihat pengaruhnya terhadap reka bentuk kulit album manakala lirik, ritma dan bunyi dalam lagu ini mempunyai unsur-unsur yang disampaikan pada kulit album. Oleh sebab itu, pengkaji mendapati reka bentuk kulit album Hijau mempunyai pengaruh dari luar dengan mengetengahkan konsep World Music, menggunakan konsep aliran muzik tradisional dan membuat pembaharuan dari muzik Afrika.

\section{2) Analisis Album Orak Arek}
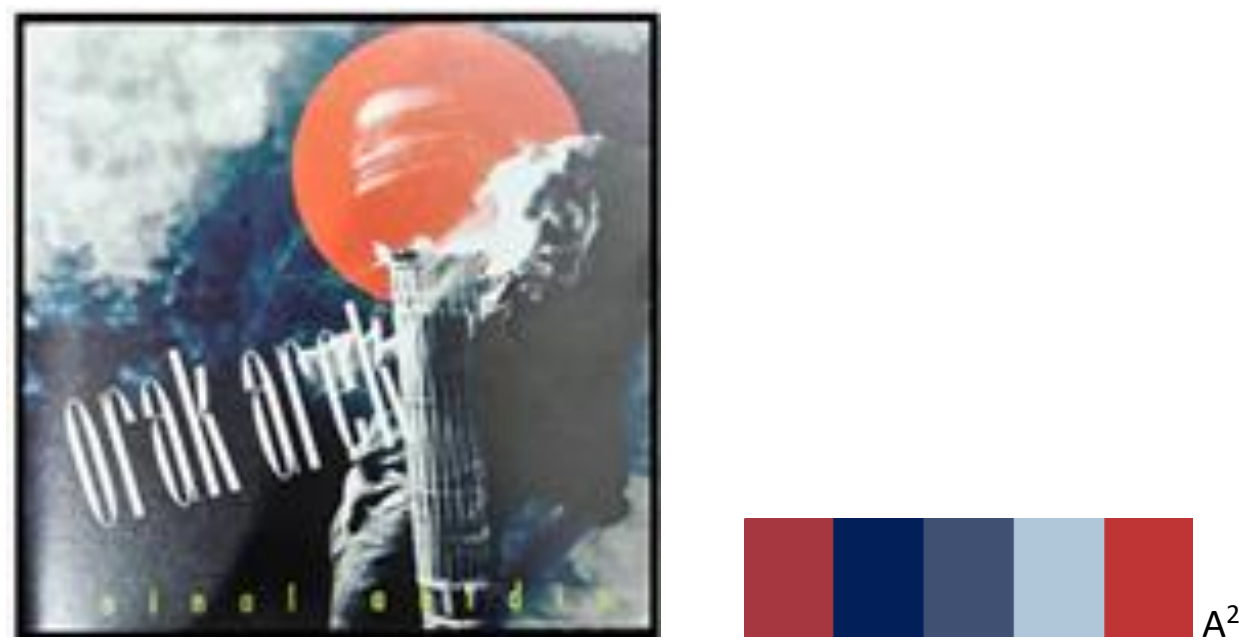

Rajah 8: Album Orak Arek

Zainal Abidin - Orak Arek

Label: Roslan Aziz Productions - 4509 93749-2, WEA - 4509 93749-2

Format: CD, Album

Negara: Malaysia

Tahun keluaran: 1993

Genre: Pop

Senarai lagu:

1. Senang-senang

2. Telaga

3. Manis

4. Insaf

5. Inayah

6. Hijau

7. Baba

8. Mana Dia 


\section{Debu Liar \\ 10. Damai IV \\ 11. Orak Arek}

Berdasarkan Rajah 8, Orak Arek merupakan album Zainal Abidin pada tahun 1993 yang dicipta oleh Amir Yussof dan lirik ditulis oleh Mukhlis Nor. Tiga elemen grafik dilihat iaitu tipografi, warna dan visual. Tipografi dalam album ini berfokus pada judul album iaitu "orak arek" yang menggunakan huruf kecil tetapi dalam saiz besar dan menggunakan warna putih. Tipografi tersebut ditulis dengan menggunakan huruf jenis Sans Serif yang bermaksud lucu atau aneh. Pengkaji mendapati tipografi jenis ini dipilih untuk menimbulkan unsur keanehan selari dengan visual yang dipaparkan.

Berdasarkan skala warna yang diambil pada kulit album Orak Arek dengan menggunakan Adobe Capture, terdapat warna merah, hitam, biru dan kelabu pada reka bentuknya. Merujuk warna dan maksud psikologi jadual 2 (Kustrianto, 2007):

- Warna merah melambangkan nafsu.

- Warna hitam melambangkan ketakutan dan kesedihan.

- Warna biru melambangkan amanah dan keselamatan.

- Warna kelabu melambangkan kesepian.

Pengkaji mendapati warna-warna di atas mempunyai kaitan dengan lagu yang disampaikan. Contohnya warna hitam melambangkan ketakutan dan kesedihan manakala warna kelabu melambangkan kesepian seperti lirik lagu Orak Arek iaitu kesedihan dan kesepian seorang anak menunggu kepulangan bapanya. Menurut Van Leeuwen (2004) dalam menganalisis sesebuah gambar dari sudut semiotik, pengkaji memilih salah satu elemen semiotik iaitu representational meaning atau makna representasi bagi melihat visual yang terdapat pada kulit album Orak Arek. Mengikut Kamus Dewan Edisi Keempat (2005), Orak Arek bermaksud kacau bilau. Berdasarkan visual yang terdapat pada album Orak Arek ini ialah gambaran seorang lelaki berdiri dan mendongak ke atas dengan mulut terbuka lalu mengeluarkan cerminan wajahnya pada permukaan bulatan merah beserta sebuah gendang di sebelahnya. Kepulan asap pada penjuru bahagian kanan atas itu pula melambangkan misteri dan ketakutan sesuai dengan maksud psikologi warna hitam serta kelabu yang digunakan.

Pengkaji mendapati pereka mengaplikasikan Ketubung Sarawak pada reka bentuk kulit album ini sebagai salah satu alatan muzik yang digunakan dalam mempersembahkan lagu Orak Arek. Menurut Mohamed Ghouse (2003, hlm. 210), ketubung ialah gendang yang berbentuk seperti hour glass dan diperbuat daripada kayu belian, tapang atau cempedak. Gendang ini biasanya digunakan untuk mengiringi tarian. Rajah 9 merupakan Ketubung Sarawak yang sama rupa dan bentuknya dengan visual dalam kulit album ini. 


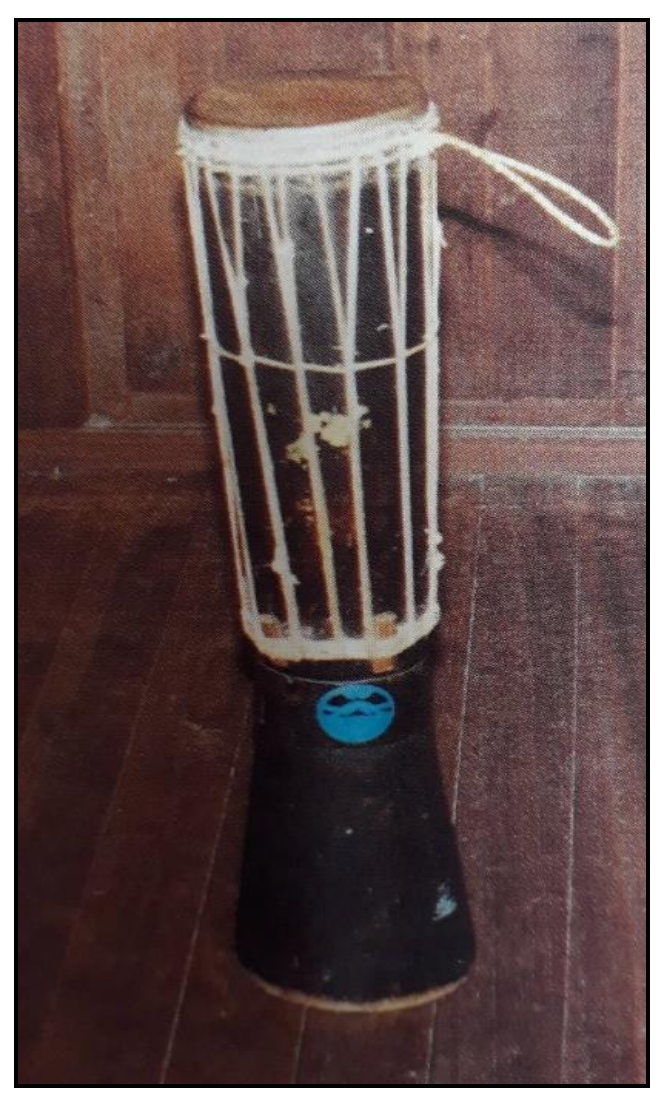

Rajah 9: Ketubung Sarawak

(Sumber: Muzik Tradisional Malaysia, hlm.212)

Manakala visual bulatan merah yang menjadi penegasan dalam kulit album ini menyerupai matahari yang sedang 'marah' atau bumi yang 'tenat'. Di tengah bulatan tersebut terdapat imej manusia dalam keadaan 'bergerak' dengan kepalanya disentak ke belakang. Dari point of view (Van Leeuwen, 2004), wajah yang 'tertinggal' diambil dari sisi, menunjukkan ia bukan subjek utama namun jelas menunjukkan wajah Zainal Abidin, penyanyi album ini. la menampakkan imej yang bercelaru dan terdapat elemen ketegangan serta konflik.

Pengkaji juga melihat bulatan merah dalam dua persepsi berbeza iaitu menyerupai logo bendera Republik Niger (Rajah 10) dan matahari merah (Rajah 11). Niger merupakan sebuah negara yang terkurung oleh daratan (landlocked) di bahagian barat Afrika. Kemiskinan Niger diperburuk oleh politik serasi dengan lagu dalam album Orak Arek yang mempunyai unsur kemiskinan dan penindasan. Seterusnya matahari merah juga dapat digambarkan sesuai dengan kedudukan reka letaknya di bahagian atas beserta kepulan asap seolah-olah gambaran sesuatu yang lepas. Gambaran ini juga ditemui dalam lirik lagu Orak Arek yang mengingatkan anaknya supaya tidak mengenangkan perkara yang lepas. 

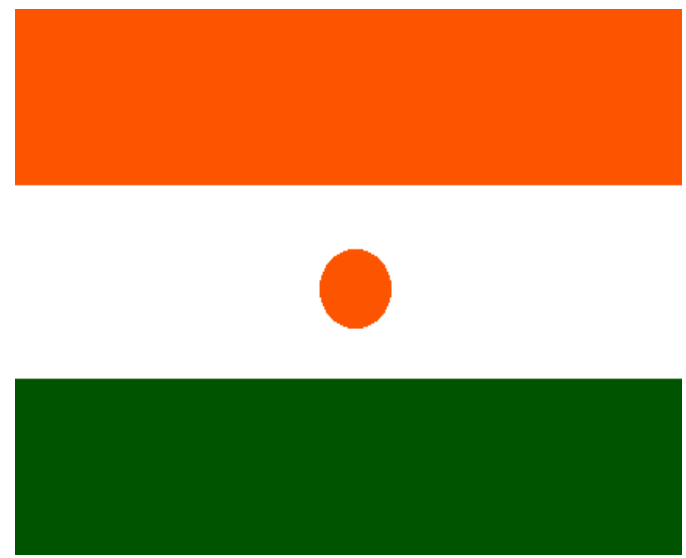

Rajah 10: Republik Niger

(Sumber: http://generasibiru1991.blogspot.com/2015/01/)

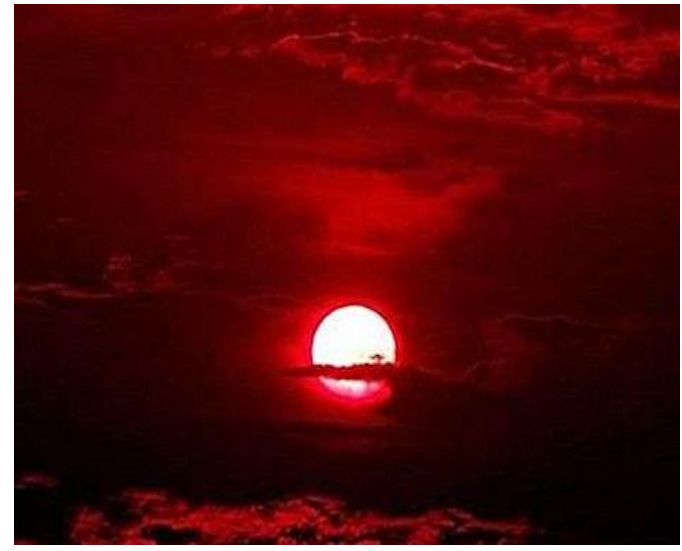

Rajah 11: Matahari Merah

(Sumber: https://may.topbrainscience.com/3191185-tip-1-why-sunset-is-red)

Dari elemen muzik pula, pengkaji mendapati ritma lagu Orak Arek yang digunakan juga berkonsepkan World Music kerana mengetengahkan muzik-muzik dari luar seperti Afrika, India, China dan Arab. Oleh itu, gabungan pelbagai muzik etnik dan moden menguatkan lagi konsep tersebut. Menurut Tan (2009), persembahan langsung Zainal di Konsert Orak Arek pada 1 Jan 1994 telah menunjukkan cara-cara seorang pemuzik menggabungkan irama dan stail Asia, Afrika serta Amerika Latin yang berbeza. Pengkaji mendapati pada permulaan muzik dalam lagu Orak Arek jelas kedengaran bunyi muzik Afrika.

'Warna bunyi' keseluruhan dalam lagu-lagu album Orak Arek adalah dari penggunaan gabungan alat muzik beserta bunyi-bunyi dari suara Zainal yang meniru gaya nyanyian atau ekspresi muzik Afrika. Antaranya ialah dram Punjabi, tabla dan gendang Melayu. Penggunaan alat muzik ini memberi kesan tradisional kepada lagu Orak Arek. Namun demikian, komplikasi lagu dari album Hijau seperti lagu Baba juga dimuatkan dalam album Orak Arek. Lagu Baba menggunakan peralatan muzik dari China iaitu Yangqin dalam persembahannya dan ini menjadikan lagu tersebut berkonsepkan World Music.

Merujuk kepada maksud Orak Arek iaitu kacau bilau maka pengkaji merungkai maksud lirik lagu ini dengan menyatakan seorang bapa yang bercelaru bila berjauhan dengan permata hatinya. Sedangkan orang sekeliling anggap mereka sentiasa senang bersama dan cuba menenangkan hati anaknya supaya tidak mengenangkan kehidupan 
mereka yang lama. Di samping itu juga terdapat gendang di sebelah Zainal dan maksud visual itu pula menjurus kepada alunan muzik yang dimainkan ketika fikirannya bercelaru mengenangkan kisah kehidupannya. Berikut merupakan keratan lirik lagu tersebut:

\section{"Usah kenang-kenang yang lama \\ Abah akan pulang permata \\ Orang ingat senang dan bersama \\ Diri merasa rata-rata \\ Orak Arek"}

(Zainal Abidin, album Orak Arek, 1993)

Berdasarkan analisis kulit album Orak Arek, pengkaji mendapati terdapat kolerasi antara grafik dan muzik dalam penghasilan kulit album ini. Penggunaan tiporafi, warna dan visual jelas dilihat pengaruhnya terhadap reka bentuk kulit album manakala lirik, ritma dan bunyi dalam lagu ini mempunyai unsur-unsur yang disampaikan pada kulit album. Oleh sebab itu, pengkaji mendapati reka bentuk kulit album Orak Arek mempunyai pengaruh yang jelas dari etnik Sarawak, Asia dan Afrika Latin.

\section{3) Analisis Album Gamal}
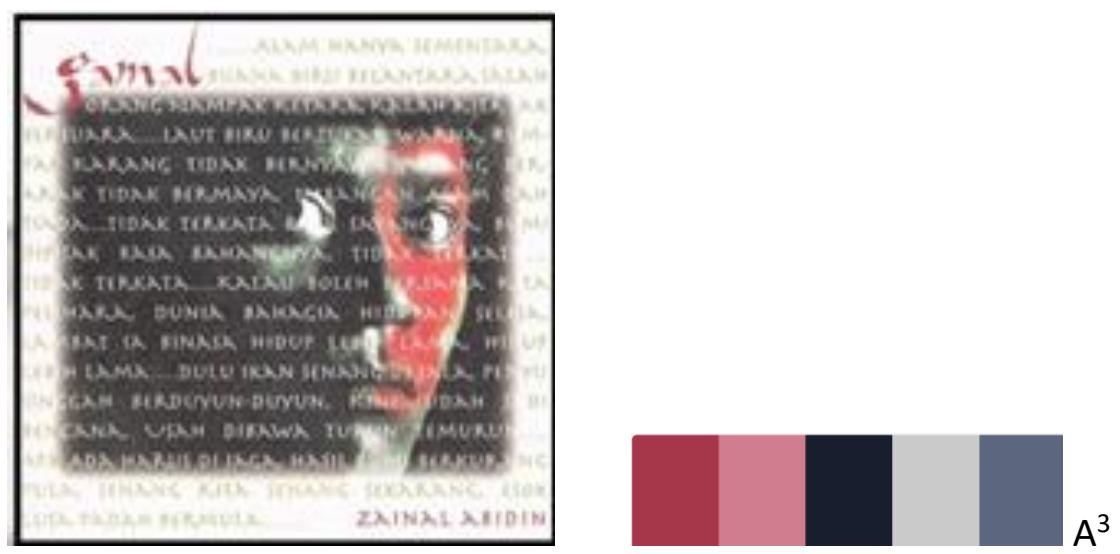

Rajah 12: Album Gamal

Zainal Abidin - Gamal

Label: WEA - 4509-97527-2

Format: $\mathrm{CD}$, Album

Negara: Germany

Tahun keluaran: 1994

Genre: Pop

Senarai lagu:

1. Bongkar muzik sarawak

2. Sabar

3. Entahlah....Mua'Lim

4. Paus

5. Randy's Song

6. Tua

7. Pantun 


\section{Garam \\ 9. Khayalan \\ 10. Damai XIII \\ 11. Jiwa \\ 12. Gamal}

Rajah 12 berjudul Gamal merupakan album Malaysia tahun 1994 oleh penyanyi Zainal Abidin dan merupakan album kedua beliau. Berdasarkan tiga elemen grafik iaitu tipografi, warna dan visual dilihat dalam kajian ini. Tipografi ditulis sepenuh kulit album ini merupakan sebahagian lirik lagu album itu sendiri yang bermula dengan tajuk album iaitu Gamal dan diakhiri dengan nama Zainal Abidin sebagai penyanyi lagu ini. Pengkaji melihat kulit album ini berdasarkan konsep semiotik dari Van Leeuwen iaitu jenis information value atau nilai maklumat. Hal ini kerana tipografi yang dibentangkan terdapat nilai maklumat yang penting dalam album Gamal. Tipografi dalam kulit album ini ditulis dengan menggunakan huruf Humanist karena memiliki goresan lembut dan natural seperti tulisan tangan. Menurut Lawson (dlm. Sawa, 2014), disebut juga Venetian kerana jenis huruf Humanist pertama dibuat di Venesia, Itali. Ciri dari jenis huruf ini iaitu memiliki kaki/sirip/serif yang patah, agak melengkung atau membulat, dan terkadang tidak rata. Kesan yang ditimbulkan adalah terang, ringan dan manusiawi. Ini jelas berkaitan dengan maksud lirik lagu ciptaan Zainal Abidin yang lebih kepada kemanusiaan.

Elemen warna dalam penghasilan reka bentuk kulit album gamal ini tidak terlalu menonjol tetapi lebih kepada warna sekata. Berdasarkan skala warna yang diambil pada kulit album ini dengan menggunakan Adobe Capture, terdapat warna merah, hitam, ungu, putih dan kelabu. Merujuk warna dan maksud psikologi jadual 2 (Kustrianto, 2007):

- Warna merah dan hitam melambangkan kekuatan, agresif dan bahaya.

- Warna ungu melambangkan misteri.

- Warna putih melambangkan tidak bersalah dan kematian.

- Warna kelabu melambangkan kesepian dan merosakkan.

Visual yang terdapat pada album Gamal ini ialah ekpresi muka seorang lelaki berambut pendek menyerupai kaum penan seperti Rajah 13 dan cat merah pada sebelah bahagian muka menyerupai amazon native seperti Rajah 14 . Visual ini mencerminkan kemarahan dan kekecewaan lelaki tersebut sepertimana lirik lagu yang dijelaskan sekaligus menjelaskan hubungkait visual dan lirik lagu dalam album ini. 


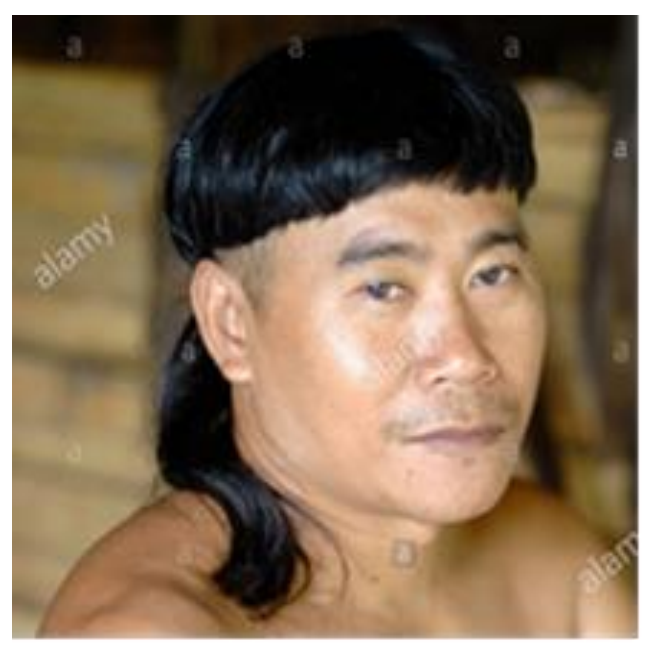

Rajah 13: Portrait of a Penan Tribesman with Traditional Haircut Sarawak Malaysia Borneo (Sumber:http://www.alamy.com/stock-photo-portrait-of-a-penan-tribesman-with-traditional-haircut-sarawl)

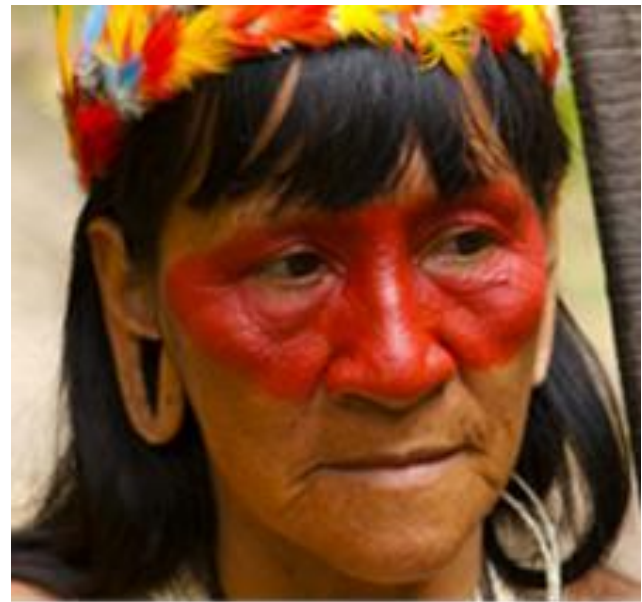

Rajah 14: Natives Ban Backpackers from Amazon Village

(Sumber: https://www.caribbeannewsdigital.com/en/noticia/natives-ban-backpackers-amazon-village)

Tan (2009, hlm.92) menyatakan Zainal Abidin bukan sahaja membuat pencampuran irama, stail dan alat muzik yang berbeza tetapi beliau juga membuat eksperimen dengan menggunakan muzik etnik dari rakaman siaran langsung. Dalam album Gamal (1994), beliau mengekspresikan nostalgia terhadap kebudayaan kaum Iban dan kumpulan etnik lain di Sarawak yang kian lenyap. Zainal Abidin menegaskan bahawa beliau cuba melaungkan kebudayaan yang kian hilang dari pandangan mata dunia seperti kebudayaan orang Iban, Penan dan Orang Hulu di Sarawak. Lagu Gamal bermula dengan petikan dari siaran langsung ensemble gong (engkerumong) orang Iban di Sarawak yang berhasrat untuk membangkitkan imej-imej aktiviti di sebuah rumah panjang orang Iban. Gabungan alat muzik tradisional seperti Serunai dalam lagu Gamal pada pertengahan lagu tersebut dimainkan. Lagu Randy's Song pula menggunakan muzik India iaitu Santoor dan Tabla pada awal lagu dimainkan.

Lagu ciptaan Randy Bernsen dan lirik oleh Zainal Abidin sendiri ini telah memenangi kategori Album Terbaik di Anugerah Industri Muzik 1995. Di dalam setiap lagu yang ditulis oleh beliau terkandung mesej cintanya kepada kemanusiaan dan alam sekitar melalui liriknya. Hal ini jelas terpapar di kulit album Gamal di mana sebahagian lirik yang ditulis atas visual kulit album ini ialah: 
"gamal....ALAM HANYA SEMENTARA, BUANA BIRU BELANTARA, SALAH ORANG NAMPAK KETARA, KALAH KITA TAK BERSUARA....LAUT BIRU BERTUKAR WARNA, RUMPAI KARANG TIDAK BERNYAWA, UDANG BERARAK TIDAK BERMAYA, IMBANGAN ALAM DAH TIADA...TIDAK TERKATA RASA SAYANGNYA, BUMI DIPIJAK RASA BAHANGNYA, TIDAK TERKATA ...TIDAK TERKATA...KALAU BOLEH BERSAMA KITA PELIHARA, DUNIA BAHAGIA HIDUPAN SELESA, LAMBAT IA BINASA HIDUP LEBIH LAMA, HIDUP LEBIH LAMA...DULU IKAN SENANG DI JALA, PENYU SINGGAH BERDUYUN-DUYUN, KINI SUDAH JADI BENCANA, USAH DIBAWA TURUN TEMURUN...APA ADA HARUS DI JAGA, HASIL BUMI BERKURANG PULA, SENANG KITA SENANG SEKARANG, ESOK LUSA PADAH BERMULA.....ZAINAL ABIDIN".

(Zainal Abidin, Album Gamal, 1994)

Merujuk lirik pantun dalam album Gamal ini, Zainal Abidin menggalakkan kesedaran tentang kehidupan marin dan dunia laut. Beliau juga menyatakan hasrat ingin mengajak masyarakat bersama-sama memelihara alam supaya kehidupan lebih selesa dan kekal untuk generasi akan datang. Menurut Tan (2009) lagi, Zainal Abidin telah digelar "Suara Hati Sosial Muzik Melayu Baru" kerana membangkitkan isu-isu seperti penagihan dadah, kemiskinan dan pemeliharaan alam sekitar di dalam lagunya.

Berdasarkan analisis kulit album Gamal, pengkaji mendapati terdapat kolerasi antara grafik dan muzik dalam penghasilan kulit album ini. Penggunaan tipografi, warna dan visual jelas dilihat pengaruhnya terhadap reka bentuk kulit album manakala lirik, ritma dan bunyi dalam lagu ini mempunyai unsur-unsur yang disampaikan pada kulit album. Oleh sebab itu, pengkaji mendapati reka bentuk kulit album Gamal mempunyai pengaruh yang jelas dari etnik Iban dan orang asli (native people).
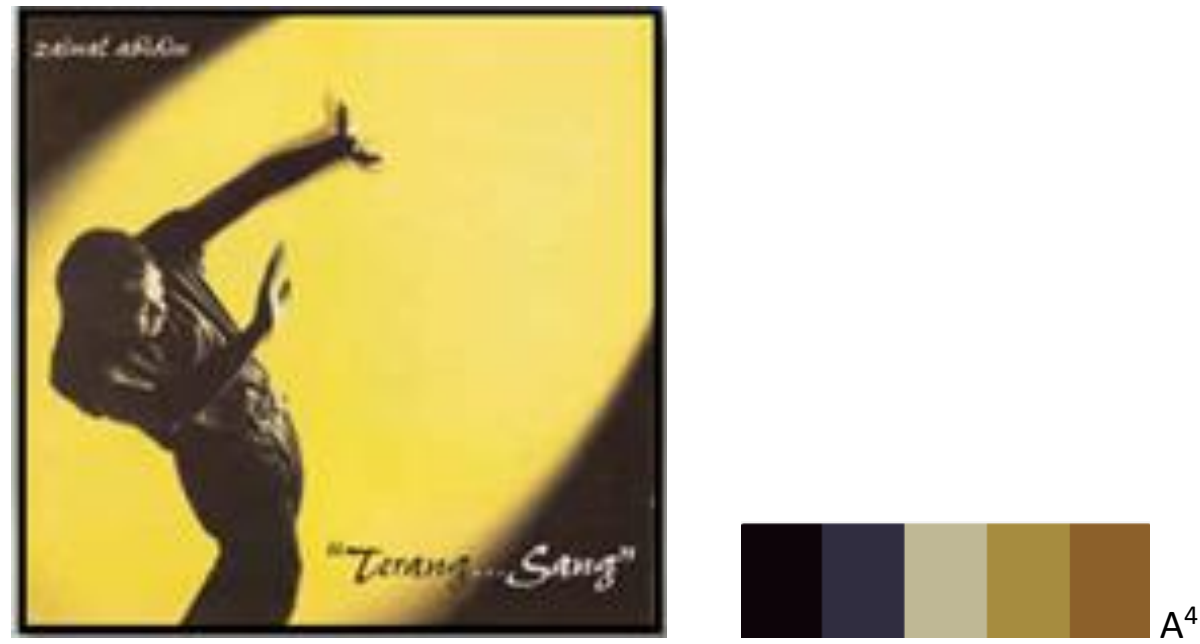

Rajah 15: Album Terangsang 
Zainal Abidin - Terang Sang

Label: WEA - 0630-13510-2

Format: CD, Album

Negara: Malaysia

Tahun keluaran: 1995

Genre: Jazz \& Pop

Senarai lagu:

1. Mutiara dan Berlian

2. Selamat Pagi Juliah

3. Kira-kira

4. Tumandang Kito

5. Muka

6. Kita Yang Sedih

7. Biologi Teknologi

8. Sejak Bila

9. Lamakah Lagi

10. Maka Al-Kisah

11. Dalang

Rajah 15 berjudul Terang Sang ialah album ketiga nyanyian Zainal Abidin yang dikeluarkan pada tahun 1995 dan telah membuat persembahan di Festival Muzik Shirataka di Jepun pada tahun yang sama. Elemen grafik iaitu tipografi, warna dan visual dilihat dalam kajian ini. Tipografi dalam album ini berfokus pada judul album iaitu "Terang..Sang". Jenis tipografi yang dipilih juga memberi penjelasan terhadap tajuk album itu sendiri. Menurut Danton Sihombing (2007), tipografi memiliki dua fungsi iaitu fungsi estetik dan fungsi komunikasi. Dalam fungsi estetik, tipografi digunakan untuk menyokong penampilan untuk kelihatan menarik, sementara dalam fungsi komunikasi tipografi digunakan untuk menyampaikan suatu mesej (maklumat) dalam bentuk teks dengan jelas dan tepat. Hal ini jelas terlihat pada tipografi terangsang yang mempunyai dua maksud iaitu terang dan sang, pengkaji mendapati pereka menggunakan permainan kata atau play of word dengan menggabungkan dua maksud menjadi satu perkataan. Dalam album ini, tipografi berbentuk roman dipilih untuk mendapatkan kesan klasik, elegan, anggun dan feminin. Bentuk tipografi yang terdapat pada kulit album terangsang juga mempunyai persamaan dengan visual yang dipaparkan iaitu imej Zainal yang berada dalam keadaan lentok seakan-akan feminin.

Berdasarkan skala warna yang diambil pada kulit album Terangsang dengan menggunakan Adobe Capture, terdapat lima warna yang berbeza pada palet namun warna hitam dan kuning yang paling menonjol pada reka bentuk kulit album ini. Merujuk warna dan maksud psikologi jadual 2 (Kustrianto, 2007):

- Warna hitam melambangkan seksualiti dan keanggunan.

- Warna kuning melambangkan optimisme dan harapan.

Oleh hal demikian, berdasarkan warna-warna di atas pengkaji mendapati kulit album terangsang mempunyai beberapa maksud yang berbeza mengikut lagu-lagu dalam album ini. Visual yang terdapat pada kulit album ini ialah gambar Zainal Abidin seolah-olah menghalang cahaya terang yang menyinarinya. Menurut beberapa elemen semiotik Van Leeuwen dalam menganalisis gambar, pengkaji telah melihat elemen point of view atau sudut pandangan 
terhadap kulit album Terangsang. Sudut pandangan yang jelas dapat dilihat ialah pada Zainal Abidin kerana satu-satunya visual yang ada pada kulit album tersebut. Secara keseluruhan visual dan warna kulit album ini menunjukkan lambang optimis seperti contoh dalam Rajah 19, walaupun kulit majalah tetapi pengkaji melihat pada warna dan visual yang ditonjolkan hampir sama dengan kulit album Terangsang.

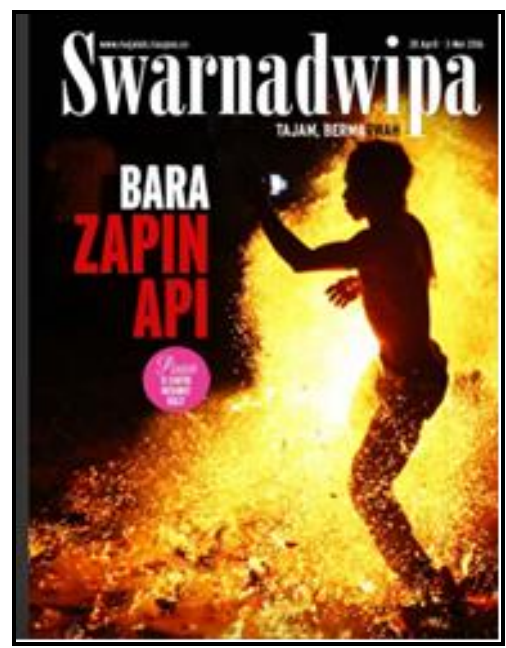

Rajah 16: Visual tema optimism

Lagu ini dicipta oleh Guy Gray/ David Pascoe dan lirik ditulis oleh Mukhlis Nor. Judul lagu "Terang...Sang" mengikut lirik lagu-lagu dalam album ini lebih kepada perasaan atau nafsu seorang lelaki terhadap wanita. Berdasarkan petikan lirik di bawah, nafsu lelaki datang dan hilang tetapi nafsu perwira datang dan terus berjuang namun mempunyai dua maksud yang berbeza. Hal ini menyerupai penggunaan tipografi tajuk album Terangsang yang menggunakan permainan kata seterusnya menghasilkan dua maksud.

\section{"Terangsang purnama dan purnama hilang... Terangsang perwira berjuang menyerang."}

(Zainal Abidin, album Terangsang, 1995)

Pengkaji mendapati penggunaan alat muzik dalam album ini lebih bersifat kontemporari namun Zainal Abidin masih mengekalkan unsur World Music dengan gabungan etnik dan moden. Kebanyakan lagu dalam album ini menggunakan bunyi gitar, namun gabungan muzik seperti gamelan, seruling dan gendang diterapkan. Contohnya bunyi muzik dalam lagu Selamat Pagi Julia dimulakan dengan bunyian Afrika diikuti dengan bunyi gamelan dan pada pertengahan lagu ini, muzik tradisional seperti Gambus dan Seruling dimainkan. Gabungan kedua-dua alat muzik ini menghasilkan sebuah lagu yang berkonsepkan tradisional.

Berdasarkan analisis kulit album Terangsang, pengkaji mendapati terdapat kolerasi antara grafik dan muzik dalam penghasilan kulit album ini. Penggunaan tipografi, warna dan visual jelas dilihat pengaruhnya terhadap reka bentuk kulit album manakala lirik, ritma dan bunyi dalam lagu ini mempunyai unsur-unsur yang disampaikan pada kulit album. Oleh sebab itu, pengkaji mendapati reka bentuk kulit album Terangsang lebih bersifat 
kontemporari namun mempunyai pengaruh dalam dan luar kerana menggunakan gabungan muzik tradisional dan Afrika.

\section{KESIMPULAN}

Berdasarkan analisis hubungan grafik dan muzik terhadap reka bentuk kulit album Zainal Abidin dalam album Hijau, Orak Arek, Gamal dan Terangsang jelas menunjukkan bahawa penghasilan kulit album Zainal Abidin mempunyai pengaruh dari luar. Ini dapat dilihat melalui album pertamanya yang mengetengahkan konsep World Music dan popular dengan lagu hits Hijau, Ikhlas Tapi Jauh dan Manis. Zainal Abidin mendapat cetusan idea untuk menggunakan konsep aliran muzik tradisional dan membuat pembaharuan dari muzik asal iaitu dari bunyian Afrika. Pengkaji juga mendapati album Orak Arek mempunyai pengaruh dari etnik Sarawak, Asia dan Afrika Latin manakala album Gamal jelas terlihat gabungan etnik iban dan orang asli (native people). Namun begitu, album Terangsang mempunyai pengaruh dalam dan juga luar negara kerana menggunakan gabungan muzik tradisional dan juga menggunakan bunyian Afrika. Secara keseluruhannya, keempat-empat buah kulit album Zainal Abidin ini mempunyai kolerasi antara grafik dan muzik dalam penghasilannya.

\section{BIODATA}

Raja Iskandar Bin Raja Halid merupakan pensyarah kanan di Fakulti Teknologi Kreatif dan Warisan, Universiti Malaysia Kelantan. Email: rajaiskandar@umk.edu.my

Salziana Binti Ibrahim merupakan pelajar ljazah Sarjana Pengajian Warisan, Fakulti Teknologi Kreatif dan Warisan, Universiti Malaysia Kelantan. Email: isalziana@yahoo.com 


\section{RUJUKAN}

Beng, T. S. (2009). Reconstructing the local: Creating new identities through "World Music" in Malaysia. In N. Rofli \& E. Khoo (Eds.), Malaysian culture: An introduction (pp. 7073). Kuala Lumpur: Jabatan Kebudayaan \& Kesenian Negara.

Guiltinan, J. P., \& Paul, W. G. (1992). Strategi pemasaran (marketing strategy): Segmentasi (segmentation), targeting dan positioning. Jakarta: Jurnal Manajemen (Pengurusan). Retrieved from https://www.academia.edu/9229978/Home_Manajemen_Pemasaran_Strategi_Pem asaran_Marketing_strategy_Segmentasi_Segmentation_Targeting_dan_Positioning? auto=download

Hanafi Mohd Tahir, Normah Mustaffa, \& Wan Amizah Wan Mahmud. (2018). Peranan visual reka bentuk kulit buku terhadap kemudahbacaan khalayak. Jurnal Komunikasi: Malaysian Journal of Communication, 34(4), 271-284.

Israr Khalid. (2016, April 16). Tapa, insan di sebalik rekaan kulit album muzik tanah air (Mustaffa Ahmad Hidzir). Astro Awani. Diperoleh dari https://www.astroawani.com/berita-hiburan/tapa-insan-di-sebalik-rekaan-kulitalbum-muzik-tanah-air-102589

Kusrianto, A. (2009). Pengantar desain komunikasi visual. Yogyakarta: CV Andi Offset.

Libeks, J., \& Turnbull, D. (2010). You can judge an artist by an album cover: Using images for music annotation. IEEE MultiMedia, 30-37. https://doi.org/10.1109/MMUL.2011.1

Miller, T. E., \& Shahriari, A. (2012). Aural analysis: Listening to the world's music (Chap. 2). In, World music: A global journey (pp. 28-30). NY: Rotledge. Retrieved from https://www.academia.edu/31051419/World_Music_A_Global_Journey_Terry_E_Mi ller_Andrew_Shahriari_pdf

Mohamed Ghouse Nasuruddin. (2003). Maksud ketubung dalam buku muzik tradisional Malaysia (pp.210) Kuala Lumpur: Perpustakaan Negara Malaysia.

Mohd Helmi Abd. Rahim, Maizatul Haizan Mahbob \& Wan Idros Wan Sulaiman (2009). Pengiklanan strategik: jenama global di Malaysia. Jurnal Komunikasi: Malaysian Journal of Communication, $25 . \quad$ Retrieved from http://ejournals.ukm.my/mjc/article/view/15117

Norshafawati Saari, Asiah Sarji, \& Fuziah Kartini Hassan Basri. (2010). Muzik dan pembangunan sosial: Paparan dasar industri hiburan dalam akhbar-akhbar di Malaysia. Jurnal Komunikasi: Malaysian Journal of Communication, 26(2), 47-65. Diperoleh dari http://ejournal.ukm.my/mjc/article/view/15108

Noresah Baharom. (2007). Definisi grafik. Kamus dewan (Edisi ke-empat). Kuala Lumpur, Malaysia: Dewan Bahasa dan Pustaka. Diperoleh dari https://prpm.dbp.gov.my/Cari1?keyword=grafik\&d=176312

Purwanto (2011). Makna konseptual berimplikasi politis pada lirik lagu slank album mata hati reformasi (pp. 2). Semarang: UNES.

Rashidah Abd Rashid, \& Naimah Salim (2009). 7 elemen dalam muzik. Unit Pendidikan Khas, Institut Pendidikan Guru Malaysia Kampus Perempuan Melayu, Melaka. Diperoleh dari https://www.scribd.com/doc/44732875/7-elemen-dalam-muzik

Sawa, B. B. (2014). Teori tipografi jenis-jenis huruf part 1. Dumet School (laman sesawang). Retrieved from https://www.dumetschool.com/blog/Teori-Tipografi-Jenis-HurufPart-1 
Synder. (2001). Music and memory: An introduction. America Syarikat: The Mit Press.

Thorgerson, S., \& Dean, R. (Eds.) (1977). Album cover album (1st ed). Limpsfield, England: Dragon's World.

Van Leeuwen, T. (2004). Visual meaning: A social semiotic approach. In C. Jewitt \& R. Oyama (Eds.), The handbook of visual analysis (pp. 2-3). London: Sage Publication.

Waluyo, H. J. (2002). Apresiasi puisi: Panduan untuk pelajar dan mahasiswa. Jakarta: Gramedia Pustaka Utama. 